логия», Казанская государственная академия ветеринарной медииины имени Н.Э. Баумана. Россия.

Григорьева Светлана Александровна, аспирант кафедры «Физиология и патологическая физиология», Казанская государственная академия ветеринарной медицины имени Н.Э. Баумана. Россия.
420029, г. Казань, ул. Сибирский тракт, д. 35. Тел.: (843) 273-97-14.

Ключевые слова: биохимический анализ; кровь; сыворотка; крысы; бромникотиновая кислота; показатели.

\title{
INFLUENCE OF BROMNICOTHIC ACID DERIVATIVES ON SOME BIO-CHEMICAL INDICATORS OF RAT BLOOD
}

Karimova Rufia Gabdelhaevna, Doctor of Biological Sciences, Professor, Head of the chair "Physiology and Pathological Physiology", Kazan State Academy of Veterinary Medicine named after N.A. Bauman. Russia.

Grigorieva Svetlana Aleksandrovna, Post-graduate Student of the chair "Physiol-ogy and Pathological Physiology", Kazan State Academy of Veterinary Medicine named after N.A. Bauman. Russia.

Keywords: biochemical analysis; blood; serum; rats; bromonicotinic acid; indica-tors.

Biochemical composition of blood of rats under load their derivatives bromonico-tinic acid have been studied. Biochemical analysis was carried out for study of a number of parameters characterizing the state of internal organs and body systems, prior to experience, an hour and one day after the introduction of the following compounds: 2,4,6trimethylpyridine-3-amide-5-bromonicotinic acid, hydroxylated-5-bromonicotinic acid, 4-methoxy-6-mailtrain-2amide-5-bromonicotinic acid and nitrate monoethanolamide 5-bromonicotinic acid. The studies were able to establish a significant increase in aspartate aminotransferase, after each administra-tion of study compounds, and there was a significant increase in triglycerides after the administration of compound 4-methoxy-6-mailtrain-2-amide-5bromonicotinic acids, and cholesterol after administration of 2,4,6-trimethylpyridine-3-amide-5-bromonicotinic acid, hydroxylated-5-bromonicotinic acid, and nitrate monoethanolamide 5-bromonicotinic acid. Decrease of LDH, LDL and HDL concentrations in rat serum was observed after administration of all compounds.

\section{ИЗУЧЕНИЕ АНТАГОНИСТИЧЕСКОЙ АКТИВНОСТИ ЛАКТОБАКТЕРИЙ}

\author{
КОЩАЕВ Андрей Георгиевич, Кубанский государственный аграрный университет имени \\ И.Т. Трубилина
}

ЛЫСЕНКО Юрий Андреевич, Кубанский государственный аграрный университет имени И.Т. Трубилина

РАДЧЕНКО Виталий Владиславович, Институт биоорганической химии имени академиков М.М. Шемякина и Ю.А. Овчинникова РАН

ЛУНЕВА Альбина Владимировна, Кубанский государственный аграрный университет имени И.Т. Трубилина

ШХАЛАХОВ Дамир Сафербиевич, Кубанский государственный аграрный университет имени И.Т. Трубилина

Представлены результаты изучения антагонистических свойств новых культур молочнокисльх микроорганизмов - Lactobacillus salivarius, Lactobacillus intermedius u Lactobacillus agilis, которые cовременными методами анализа микробиома были выделены и идентифицированы из желудочно-кишечного тракта перепела. Ингибирующая активность тестируемых культур лактобактерий изучалась методами агаровых слоев, лунок, перпендикулярных штрихов и капель в различных модификациях. В качестве тест-культур применялисъ условно-патогенные итаммы, которые были выделены на птицефабриках Краснодарского края. Результаты изучения антагонистической активности молочнокисльх микроорганизмов показали, что все три итамма проявляли ингибирующее действие на рост тест-культуры, но в разной степени. Установлено, что зона задержки тест-культур при использовании различных диффузионных методов находилась в пределах 2-14 мм. Использование метода перпендикулярных штрихов показало зону ингибирования роста - 5-14 мм, метода лунок- 2-3 мм, метода капель - 3-5 мм и метода агаровых слоев - 2-5 мм. Выявлено, что Lactobacillus intermedius проявлял данное свойство активнее других лактобактерий. Изученные штаммы микроорганизмов в разной степени проявляют антагонистическую активность в отношении условно-патогенной тест-культуры, в связи с чем данные лактобаииллы перспективны и могут быть включены в состав биопрепаратов микробного происхождения для птицеводства.

Введение. В настоящее время проблема обеспечения населения продуктами питания непосредственно связана с развитием животноводства, в том числе птицеводства $[1,7]$. В связи с этим государственная аграрная политика РФ до 2020 г. определила одну из главных задач - обеспечить население продукцией сельскохозяйственного назначения отечественного производства. Для достижения поставленной цели необходимо до 2020 г. снизить долю импорта мясных и молоч- 
ных продуктов до 13 \% [5]. Потребление мяса населением РФ будет почти полностью удовлетворяться за счет собственного производителя. Повышение показателей эффективности данной отрасли возможно при применении инновационных технологий в кормлении и содержании сельскохозяйственных животных и птицы, направленных на получение здорового поголовья $[4,8]$.

Одна из главных проблем ветеринарии - появление микроорганизмов с патогенными свойствами, которые приобрели устойчивость к ряду антибиотических препаратов [2]. Повсеместное применение таких антибиотиков в составе кормовых рационов способствует снижению собственного иммунитета сельскохозяйственных животных и птицы. При этом наблюдается угнетение в желудочно-кишечном тракте собственного микробного фона, что приводит к развитию болезней. Поэтому для профилактики и лечения болезней, вызванных нарушением микробного баланса, актуальным является применение биопрепаратов микробного происхождения [6].

Естественная нормофлора принимает активное участие в поддержании колонизационной устойчивости слизистой оболочки кишечника и имеет большое значение в предупреждении заболеваний. Выделяя в среду кишечника антибиотические субстанции, она способствует ингибированию роста патогенной и условно-патогенной микрофлоры, которая является возбудителем различных внутренних незаразных заболеваний [4]. Полезная микрофлора в составе биопрепаратов оказывает противоинфекционное, иммуномодуляторное воздействие на организм, повышает защитные функции, способствует стимулированию моторики и экскреторной функций кишечника. Биопрепараты на основе живой микрофлоры используют как для профилактики, так и для терапии. Однако для каждого вида животного и птицы характерны свои микроорганизмы, обладающие пробиотическими свойствами. В связи с этим не всегда пробиотики, разработанные на основе живых культур микроорганизмов, которые были выделены из желудочно-кишечного тракта, от одного вида живого организма проявляют эффективность при использовании у другого вида [3].

Таким образом, разработка биопрепаратов на основе полезной нативной микрофлоры, которые могут заменить антибиотики, является актуальным направлением, а исследование свойств новой выделенной полезной микрофлоры носит как научный, так и практический характер.

Цель данной работы - изучение различными диффузионными методами антагонистических свойств новых культур лактобацилл, выделенных из желудочно-кишечного тракта (ЖКТ) перепелов, в отношении условно-патогенной микрофлоры.

Методика исследований. Исследования проводили на базе ФГБНУ «Краснодарский центр по зоотехнии и ветеринарии - Краснодар- ский НИВИ», а также в экспериментальной лаборатории кафедры биотехнологии, биохимии и биофизики КубГАУ. Объекты исследований Lactobacillus salivarius, Lactobacillus intermedius и Lactobacillus agilis, которые современными методами анализа микробиома были выделены и идентифицированы из ЖКТ перепела [3].

Антагонистическую активность молочнокислых микроорганизмов изучали диффузионными методами (in vitro): агаровых слоев, лунок, перпендикулярных штрихов и капель в различных модификациях. В качестве тест-культуры использовали Staphylococcus aureus, выделенную на птицефабрике Приморской от цыплят-бройлеров, а также Escherichia coli, выделенную на птицефабрике Новомышастовской от кур-несушек.

Одним из недостатков классического метода перпендикулярных штрихов является то, что продуцент-антагонист и тест-организм культивируют на одинаковой среде, в то время как среда может быть не для всех питательной, при тестировании антагонистической активности выделенных лактобацилл использовали «чашечный» метод М. Литвинова (1947) в модификации Н.С. Егорова (1965). В чашки Петри разливали агаризованную среду для молочнокислых микроорганизмов, а затем добавляли незначительное количество бульонной культуры изучаемой лактобациллы. Круговыми движениями перемешивали содержимое чашки и оставляли на некоторое время до уплотнения агара. Затем чашки с культурой перемещали в термостатируемый шкаф при $37{ }^{\circ} \mathrm{C}$ на 48 ч. Через 2 суток в стерильном боксе вырезали из чашки $1 / 2$ агаризованной питательной среды с выросшей молочнокислой культурой. В освободившую от питательной среды часть чашки заливали сухой питательный агар. После его застывания рассевали штрихом суточные культуры тестштаммов условно-патогенных микроорганизмов. Чашку вновь отправляли в термостат, где культивировали при тех же условиях в течение 24 ч. Степень антагонистической активности изучаемых культур лактобактерий оценивали по размеру зоны ингибирования (задержки) тестштамма на границе со штрихом роста.

Для изучения антагонистической активности методом лунок в слое агаризованной питательной среды, на которой засеян тест-штамм, пробочным сверлом делали небольшие лунки диаметром 4-6 мм. В образовавшиеся пустоты (лунки) заливали изучаемые культуры молочнокислых бактерий в концентрации не менее $1 \times 10^{9} \mathrm{KOE} /$ мл. Далее лабораторные чашки выдерживали 30 мин при $+4{ }^{\circ} \mathrm{C}$, а затем перемещали в термостатируемый шкаф при температуре $37^{\circ} \mathrm{C}$ в течении 18-24 ч. Зону задержки роста тестштамма оценивали вокруг лунки, засеянной тестируемой культурой лактобактерий.

Для осуществления метода агаровых слоев на агаризованную питательную среду для 
молочнокислых бактерий наносили бляшками 48-часовую культуру лактобактерий и выращивали при $37^{\circ} \mathrm{C}$ в течение 24 и 48 ч. После на крышку чашки Петри тонким слоем наносили хлороформ и оставляли чашку дном вверх в течение 5 мин. Убитые под воздействием паров хлороформа микроорганизмы перемещали в термостат на 30 мин для испарения паров раствора. Далее на чашки Петри следующим слоем разливали полужидкий мясо-пептонный агар с равномерно распределенной в нем тесткультурой и вновь инкубировали при $37^{\circ} \mathrm{C}$ в течение суток. Результат считался положительным в случае появления вокруг бляшки зоны ингибирования роста для культур, продуцирующих антибактериальные вещества.

При изучении антибиотических свойств методом капель на поверхность подсушенной питательной агаровой среды наносили капли изучаемых культур молочнокислых микроорганизмов. После культивирования в термостате при $37^{\circ} \mathrm{C}$ в течение 24-48 ч в чашки Петри поверх агара заливали слой полужидкой питательной среды, в которую был засеян тест-штамм в концентрации $10^{5} / \mathrm{cm}^{3}$. Далее проводили инкубацию чашек в термостате в течение 18-24 ч до появления зон задержки роста тест-культуры.

Результаты исследований. Изучение ингибирующей активности молочнокислых микроорганизмов показало, что все три штамма в разной степени проявляли антибактериальное действие на рост тест-культуры. Установлено, что зона задержки тест-культур при использовании различных диффузионных методов находилась в пределах 2-14 мм. Использование модифицированного метода перпендикулярных штрихов показало зону ингибирования роста - 5-14 мм, метода лунок - 2-3 мм, метода капель - 3-5 мм и метода агаровых слоев - 2-5 мм. Результаты изучения антагонистической активности тестируемых культур представлены в таблице.

При изучении антагонистической активности методом агаровых слоев установлено, что зона ингибирования роста Escherichia coli и Staphylococcus aureus при инкубировании Lactobacillus agilis составила 2 и 3 мм, а при выра- щивании Lactobacillus salivarius - 3 и 2 мм соответственно. При этом зона задержки роста тесткультур под действием Lactobacillus intermedius была максимальной и составила 3 и 5 мм.

Метод лунок показал аналогичное превосходство Lactobacillus intermedius в проявлении антибиотических свойств перед другими изучаемыми лактобактериями, однако оно было незначительно и обнаружилось при действии на Staphylococcus aureus, зона задержки роста которого составила 3 мм, а во всех остальных случаях - 2 мм.

При изучении антагонистической активности методом перпендикулярных штрихов выявлено, что под влиянием Lactobacillus salivarius зона задержки роста Escherichia coli и Staphylococcus aureus составила 8 и 5 мм соответственно. Под действием ингибирующих агентов, выделяемых Lactobacillus agilis, зона задержки роста тест-культур составила 9 мм (Escherichia coli) и 10 мм (Staphylococcus aureus). Следует отметить, что наибольшей ингибирующей активностью обладал Lactobacillus intermedius, под действием которого зона задержки роста Escherichia coli составила 11 мм, а Staphylococcus aureus - $14 \mathrm{Mm}$.

При тестировании антагонистической активности выделенных из кишечника перепелов лактобацилл методом капель установлено, что все культуры одинаково проявили свое действие на рост Escherichia coli. Зона задержки роста данной тест-культуры составил 3 мм. Однако наблюдались различия при действии лактобактерий на Staphylococcus aureus. Так, зона ингибирования роста золотистого стафилококка при культивировании с Lactobacillus salivarius и Lactobacillus agilis составила 4 мм, в то время как Lactobacillus intermedius зону задержки составил 5 мм.

Заключение. Изученные штаммы микроорганизмов в разной степени проявляют антагонистическую активность в отношении условнопатогенной тест-культуры. В связи с этим данные лактобациллы перспективны и могут быть включены в состав биопрепаратов микробного происхождения для птицеводства. Однако особое внимание необходимо уделить Lactobacillus intermedius, которая показала наилучшую ингибирующую активность.

Антагонистическая активность изучаемых лактобактерий в отношении тест-культур

\begin{tabular}{|c|c|c|c|}
\hline \multirow[b]{2}{*}{ Тест-культура } & \multicolumn{3}{|c|}{ Лактобактерии } \\
\hline & $\begin{array}{c}\text { Lactobacillus } \\
\text { agilis }\end{array}$ & $\begin{array}{c}\text { Lactobacillus } \\
\text { intermedius }\end{array}$ & $\begin{array}{c}\text { Lactobacillus } \\
\text { salivarius }\end{array}$ \\
\hline \multicolumn{4}{|c|}{ Метод агаровых слоев } \\
\hline Escherichia coli & 2 & 3 & 3 \\
\hline Staphylococcus aureus & 3 & 5 & 2 \\
\hline \multicolumn{4}{|c|}{ Метод лунок } \\
\hline Escherichia coli & 2 & 2 & 2 \\
\hline Staphylococcus aureus & 2 & 3 & 2 \\
\hline \multicolumn{4}{|c|}{ Метод перпендикулярных штрихов } \\
\hline Escherichia coli & 9 & 11 & 8 \\
\hline Staphylococcus aureus & 10 & 14 & 5 \\
\hline \multicolumn{4}{|c|}{ Метод капель } \\
\hline Escherichia coli & 3 & 3 & 3 \\
\hline Staphylococcus aureus & 4 & 5 & 4 \\
\hline
\end{tabular}


Работа проведена при поддержке гранта Президента РФ (МК-961.2017.11 (Договор № 14.W01.17.961-MK).

\section{СПИСОК ЛИТЕРАТУРЫ}

1. Джаилиди Г.А., Лысенко А.А., Кривонос Р.А. Эпизоотические особенности ящура крупного рогатого скота // Ветеринария Кубани. - 2013. - № 5 . C. 15-17.

2. Жолобова И.С, Кощаев А.Г., Лунева А.В. Эффективность использования активированных растворов хлоридов при лечении собак с хирургическими заболеваниями / / Труды Кубанского государственного аграрного университета. - 2012. - № 36. - С. 270-272.

3. Идентификация штаммов автохтонной микрофлоры - основы биопрепаратов лечебно-профилактического действия / В.В. Радченко [и др.] // Биофармацевтический журнал. - 2016. - Т. 8. - № 1. C. $3-12$.

4. Кощаев А.Г., Лысенко Ю.А., Лунева А.В. Пробиотическая кормовая добавка в кормлении перепелов // Зоотехния. -2015 . - № 10. - С. 4-6.

5. Лечение атонии преджелудков жвачных пропионовой кислотой / А.Ч. Ли [и др.] // Труды Кубанского государственного аграрного университета. - 2011. № 32. - C. 171-173.

6. Фармакологическое обоснование применения пробиотика Промомикс С / А. Ширина [и др.] // Птицеводство. - 2013. - № 9. - С. 35-39.

7. Щербатов В.И., Бачинина К.Н., Кузько В.О. Биологические ритмы молодняка перепелов // Сб. науч. тр. Северо-Кавказского науч.-исслед. ин-та животно- водства. - 2017. - Т. 2. - № 6. - С. 288-292.

8. Щербатов В.И., Бачинина К.Н. Способ отбора перепелов // Политематический сетевой электронный научный журнал Кубанского государственного аграрного университета. - 2018. - № 138. - С. 140-148.

Кощаев Андрей Георгиевич, д-р биол. наук, проф., проректор по научной работе, Кубанский государственный аграрный университет имени И.Т. Трубилина. Россия.

Лысенко Юрий Андреевич, канд. биол. наук, доцент кафедры «Биотехнология, биохимия и биофизика», Кубанский государственный аграрный университет имени И.Т. Трубилина. Россия.

350044, г. Краснодар, ул. Калинина, 13.

Тел.: (961) 518-07-22.

Радченко Виталий Владиславович, канд. биол. наук, научный сотрудник лаборатории белков гормональной регулящии, Институт биоорганической химии имени академиков М.М. Шемякина и Ю.А. Овчинникова РАН. Россия.

117997, г. Москва, ГСП-7, ул. Миклухо-Маклая, 16/10.

Тел.: (495) 336-55-11; e-mail: vitalyradchenko@yandex.ru.

Лунева Альбина Владимировна, канд. биол. наук, доцент кафедры «Паразитология, ветсанэкспертиза и зоогигиена», Кубанский государственный аграрный университет имени И.Т. Трубилина. Россия.

Шхалахов Дамир Сафербиевич, аспирант кафедры «Биотехнология, биохимия и биофизика», Кубанский государственный аграрный университет имени И.Т. Трубилина. Россия.

350044, г. Краснодар, ул. Калинина, 13.

Тел.: (961) 518-07-22.

Ключевые слова: антагонистические свойства; лактобактерии; Escherichia coli; Staphylococcus aureus; задержка pocma.

\section{THE STUDY OF ANTAGONISTIC ACTIVITY OF LACTOBACILLI}

Koshchaev Andrey Georgievich, Doctor of Biological Sciences, Professor, Kuban State Agrarian University named after I.T.Trubilin. Russia.

Lysenko Yury Andreevich, Candidate of Biological Sciences, Associate Professor of the chair "Biotechnology, Biochemistry and Biophysics", Kuban State Agrarian University named after I.T.Trubilin. Russia.

Radchenko Vitaly Vladislavovich, Candidate of Biological Sciences, Scientific Researcher of the laboratory of proteins of hormonal regulation, Shemyakin-Ovchinnikov Institute of bioorganic chemistry. Russia.

Luneva Albina Vladimirovna, Candidate of Biological Sciences, Associate Profes-sor of the chair "Prasitology, Veterinary Expertise and Zoohygiene, Kuban State Agrarian University named after I.T.Trubilin. Russia.

Shkhalakhov Damir Saferbievich, Post-graduate Student of the chair "Biotechnol-ogy, Biochemistry and Biophysics”, Kuban State Agrarian University named after I.T.Trubilin. Russia.

Key words: antagonistic properties; lactobacilli; Escherichia coli; Staphylococcus aureus; growth retardation.

There were presented the results of the study of different diffusion methods of an-tagonistic properties of new cultures of lactic acid microorganisms - Lactobacillus salivarius, Lactobacillus intermedius and Lactobacillus agilis, which were sorted out by modern methods of the analysis of microbioma and identified from gastrointestinal tract of a quail. The inhibitory activity of tested cultures of lactic bacteria was studied by such methods as: method of agarinic layers, holes, perpendicular streaks and drops in different modifications. The work was done on the base of Krasnodar scientific-research veterinary institute as well as in the laboratory of the chair of biotechnology, biochemistry and biophysics of Kuban State Agrarian Uni-versity. Opportunistic strains which were sorted out in the poultry factories of the Krasnodar Territory as a test-culture. The results of the study of the antagonistic activity of lactic acid microorganisms showed that all three strains showed the in-hibitory effect on the growth of the test culture, but to a different extent. There was stated that the zone of a test-culture delay under use of different diffusion methods in limits 2-14 $\mathrm{mm}$. The use of perpendicular strain method showed the zone of inhibitory growth $-5-14 \mathrm{~mm}$, method of hole $-2-3 \mathrm{~mm}$, method of drops - 3-5 $\mathrm{mm}$ and method of agarinic layers - 2-5 mm. However there was stated that Lactobacillus intermedius manifested the present property more active than other lactic bacteria. So, for example, the zone of delay of growth of Escherichia coli by the method of perpendicular strains comprised $11 \mathrm{~mm}$ and a Staphylococcus aureus - $14 \mathrm{~mm}$, while at the testing of Lactobacillus salivarius and Lactobacillus agilis, the zone of test-culture delay amounted 8 and $5 \mathrm{~mm}$, and as well as 9 and $10 \mathrm{~mm}$, respectively. In general, the studied strains of microorganisms to different degree exhibit the antagonistic activity against the opportunistic test culture, in connection with which, lactobacilli data are promising and can be included in the composition of microbial biological products for poultry. 